Sir John Russell comments: "the broad conclusion was that hunger need not be feared for at least the next forty years and this result could be achieved on present knowledge if only it were properly applied. . . These optimistic conclusions from such an authoritative group come as a great relief after the pessimistic gloom that has long surrounded the subject". The booklet may not produce this impression on all its readers, who should be many.

W. R. Aykroyd

\title{
PLANT PHENOLICS GROUP OF NORTH AMERICA
}

$\mathrm{T}$ HE recent increase of interest in the biology and chemistry of the phenolic constituents of plants becomes immediately apparent on inspection of the lists of contents of many of the world's biological and chemical publications. However, workers in the various fields embraced by an interest in the plant phenolics are widely scattered throughout departments of botany, biology, biochemistry, chemistry, microbiology, pharmacy, pharmacology and forestry, in universitios, research institutes, government agencies and in industry. There is consequently almost no common meeting place for people with such interests, with the result that there is little discussion and exchange of information between workers of the different disciplines.

In 1956, the Plant Phenolies Group was founded in Great Britain as an informal organization with the aims of promoting "the advancement of the knowledge of phenolic and related constituents of plants in respect of their chemistry, function, biosynthesis, effect on plant and animal physiology and pathology, and the application of such knowledge in agriculture and industry". Since its founding the Plant Phenolics Group has been very successful in achieving these aims, holding two or three meetings a year. The proceedings of many of these meetings have been published.

At the ninth International Botanical Congress in Montreal in 1959, discussions with various biochemists and physiologists interested in plant phenolic substances led to the idea that a sister organization be formed in North America. The largest problem with forming such a group on this continent, of course, results from its geographical size, which would prohibit such a group from meeting more frequently than once a year.

An organizing committee, consisting of Dr. T. A. Geissman (University of California), Dr. V. C. Runeckles (Imperial Tobaceo Co. of Canada) and
Dr. G. H. N. Towers (McGill University), distributed a letter to interested persons in 1960 , the response to which was so enthusiastic as to encourage the committee to make plans for an inaugural meeting. This was held at Colorado State University, Fort Collins, during August 31-September 1, and took the form of a symposium on the biochemistry of plant phenolic substances. The meeting was sponsored by the National Science Foundation under the direction of Mr. G. Johnson of Colorado State University, and Dr. Geissman. The papers presented were: "Recent Studies on the Structures and Bitterness of the Flavonoid Glycosides of Citrus" (Dr. R. M. Horowitz, U.S. Department of Agriculture, Albany, California), "Biosynthesis of Plant Phenols" (Dr. S. A. Brown, National Research Council, Saskatoon), "Naturally Occurring Biflavonyls" (Dr. N. Kawano, University of Nagasaki, Japan), "Metabolic Fate of Phenolic Substances in Animals" (Dr. A. N. Booth, U.S. Department of Agriculture, Albany), "Role of Plant Phenolics in Disease Resistance and Immunity" (Dr. I. Uritani, Nagoya University, Japan), "Melanin and its Formation" (Dr. G. A. Swan, University of Durham) and "Estrogenic-like Substances in Plants" (Dr. E. M. Bickoff, U.S. Department of Agriculture, Albany). It is hoped that the proceedings of the symposium will be published.

More than sixty delegates attended the symposium, the last session of which was devoted to founding the Plant Phenolics Group of North America. The officers elected were: president, Dr. S. H. Wender (University of Oklahoma); vice-president, Dr. L. Jurd (U.S. Department of Agriculture, Albany); hon. secretary-treasurer, Dr. V. C. Runeckles.

It was agreed at the first meeting that membership of the Plant Phenolics Group of North America be open to all persons interested in the Group's aims, on applica tion to the secretary, Dr. V. C. Runeckles, P.O. Box 6500, Montreal, Quebec. V. C. RuneckIes

\section{RESEARCH WITH TROPICAL PLANTS}

\begin{abstract}
$\mathrm{T}$ HE Tropical Products Institute of the Department of Scientific and Industrial Research is continuing its work on the examination of plants from tropical territories, and a recent report outlines the scope of investigations carried out during $1960 *$.

Any new sources of drugs could be of great economic benefit to the countries to which the plants are indigenous, and the Institute's activities follows representations from overseas governments for technical assistance in this field. Already 314 plants have been tested, including specimens from North Borneo

* Department of Scientiflc and Industrial Research. The Report of the Tropical Products Institute Committee, with the Report of the Tropical Products Institute. Pp. viii +40. (London: H.M.S.O., 1961.) 38.
\end{abstract}

as well as samples from Kew Gardens. A number of alkaloid-containing plants have been found and are being subjected to further tests. The Director of the Institute reports the expansion of economic and longterm research work by the Institute to meet the needs of rapidly developing tropical countries. This reflects a trend away from short-term inquiries in order to help newly established laboratories overseas with their research and development problems. Even more important is the demand for qualified manpower in the territories themselves, and the Institute has helped by sending visiting scientists to 39 overseas territories and by training research workers from five different tropical countries. More than 900 